\title{
THERMAL ENHANCED OIL RECOVERY (TEOR) USING GEOPRESSURED-GEOTHERMAL BRINE
}

Published December 1989

Prepared by the

Idaho National Engineering Laboratory

EG\&G Idaho, Inc.

Idaho Falls, Idaho 83415

for the

U. S. Department of Energy

Idaho Operations Office

Under DOE Contract No. DE-AC07-76ID01570 


\section{DISCLAIMER}

This report was prepared as an account of work sponsored by an agency of the United States Government. Neither the United States Government nor any agency Thereof, nor any of their employees, makes any warranty, express or implied, or assumes any legal liability or responsibility for the accuracy, completeness, or usefulness of any information, apparatus, product, or process disclosed, or represents that its use would not infringe privately owned rights. Reference herein to any specific commercial product, process, or service by trade name, trademark, manufacturer, or otherwise does not necessarily constitute or imply its endorsement, recommendation, or favoring by the United States Government or any agency thereof. The views and opinions of authors expressed herein do not necessarily state or reflect those of the United States Government or any agency thereof. 


\section{DISCLAIMER}

Portions of this document may be illegible in electronic image products. Images are produced from the best available original document. 


\section{THERMAL ENHANCED OIL RECOVERY (TEOR) USING GEOPRESSURED-GEOTHERMAL BRINE}

\section{ABSTRACT}

This white paper presents a unique plan for an Oil Industry-DOE cost sharing research project for Thermal Enhanced Oil Recovery (TEOR) of medium and heavy oil using geopressured-geothermal brine. This technology would provide an environmentally clean method of recovery as opposed to the burning of crude oil or natural gas used widely by the industry, but presently under scrutiny by federal and state air quality agencies, as well as provide an alternative to the very expensive operational and mechanical problems associated with heating water on the surface for injection.

An example test reservoir is a shallow, small structural reservoir about 1-1/2 miles long by $1 / 2$ mile wide. It is presently producing heavy oil (18.6 API gravity) from 5 wells, and is marginally economic.

One of three nearby geopressured-geothermal wells could be re-entered and recompleted to supply about $400^{\circ} \mathrm{F}$ brine from 13-16,000 feet. This brine can be used to heat and drive the heavy oil. It is anticipated that about one million barrels of oil may be recovered by this project. Over 3 million barrels are estimated to be in place; only $2.7 \%$ of the oil in place has been produced.

The suggested teaming arrangement includes:

1. EG\&G Idaho, Inc., which presently provides technical and management support to DOE in the Gulf Coast Geopressured-Geothermal Program. EG\&G would supply coordination, management and technical support to DOE for the Thermal Enhanced Oil Recovery Project.

2. A small business which would supply the field, geologic and well data, production wells, and production operation. They would cost-share the project and provide revenue from increased production ( $5 \%$ of increased production) to help offset DOE costs. Though DOE would cost-share brine supply and injection system, they would not assume well ownership. The small business would supply engineering and operations for brine supply, injection system, and collection of field producing and injection data.

PHASE I - Geologic, reservoir, feasibility and economic studies, and hot water flooding design would be made for the proposed project, and geopressured production well and leases will be investigated.

PHASE II - If the results of the feasibility studies warrant proceeding, geopressured production well and leases will be obtained.

PHASE III - Operation of project, collection of injection and production data, reservoir and environmental monitoring and evaluation will be completed. This would be concluded by a final report including an evaluation of methodology for regional application in the Texas Gulf Coast. The project will be turned over to the operator for operation to depletion. 
The final report will also address the feasibility of geopressured-geothermal enhanced recovery of oil in other locations. There is a regional trend of similar reservoirs along the Texas Gulf Coast, where this technology could be immediately applied, as well as other areas, such as the San Joaquin Basin, where the country's largest heavy oil reserves are located.

If this process is proven successful, many millions of barrels of oil could be added to this country's recoverable reserves. Further, hundreds of marginally economic fields may not require immediate plugging.

The total estimated cost for this five-year program is approximately $\$ 16$ million. Cost-sharing by the small business will reduce the DOE funds required over five years to $\$ 13$ million less cost-shared oil produced. To initiate this program would require a first year funding level of approximately $\$ 1$ million. This is not a formal proposal and is not a commitment by EG\&G Idaho, Inc. A formal breakdown of financial information will be provided with a formal request for proposal. 


\section{TECHNICAL DISCUSSION}

\section{A. INTRODUCTION}

The proposed Alworth Field project is typical of the type fields found in the "Mirando" trend of South Texas (C. E. Kimmell, 1989). See Figure 1.

\section{History of the Trend}

The first recorded production of oil in this trend was at Charco Redondo Field in Zapata County, Texas, in 1913, at a depth of 160 feet. Starting in the early 1920s, such fields as Carolina-Texas, West Cole, Alworth, Henne-Winch-Farris, Randado, Albercas, Aviators, Bruni, Cole and Government Wells were discovered. During the depression years, until 1937, very few discoveries were made; however, in the late 1930s and accelerating during the war years, many discoveries of major oil reserves were drilled and exploited. Discoveries continue to the present; however, since this is a mature exploration area, the later discoveries are small.

The production practices up until the 1960s can best be described as chaotic and were governed by the "law of capture". In most instances, the producers ignored engineering conservation practices and blew down the reservoir energy by flaring the produced gas and dumping produced salt water on the ground. This resulted in primary recovery factors of many reservoirs being below $10 \%$ of the oil-inplace.

\section{Geological Setting}

The producing rocks of this "Mirando" Trend are from Upper Eocene Jackson and Yegua Formations and occur from depths of 160 to 5,000 feet. The trapping mechanisms are stratigraphic and/or combination stratigraphic-structural traps occasioned by longshore bars pinching out up-dip over a terrace or associated fault structures. The oil produced varies from $16^{\circ}$ to $45^{\circ}$ gravity, with the gravity being associated with depth and is, almost without exception, a sweet paraffin based crude. The lower gravity oils are known as South Texas Heavy. The crude purchasers pay a small bonus for this over other crudes in the area.

The reservoir rocks are usually quite porous and permeable and, where an effective water drive is present, and the viscosities of the oil are low, recoveries have been excellent. Where an effective water drive is not present, and a gas cap or gas-in-solution drive is the reservoir energy, and the oil has high viscosities, the recoveries have been fair to very poor.

Some of the larger fields have had pressure maintenance-waterflood programs in existence for years with varying results.

Most of the "Mirando" Trend production is located in the four county area of Duval, Webb, Jim Hogg and Zapata Counties, with a small portion of western Starr County included. The trend is approximately 30 miles wide and 110 miles long.

The Railroad Commission records reflect that there are 87 fields in this trend, producing oil of a gravity of $21.5^{\circ}$, or lower. These 87 fields have produced a total of $319,034,677$ barrels of oil to $1 / 1 / 88$ and produced 1,598,191 barrels of oil in 1987. Of the 87 fields, all but 10 recorded production in 1987. 


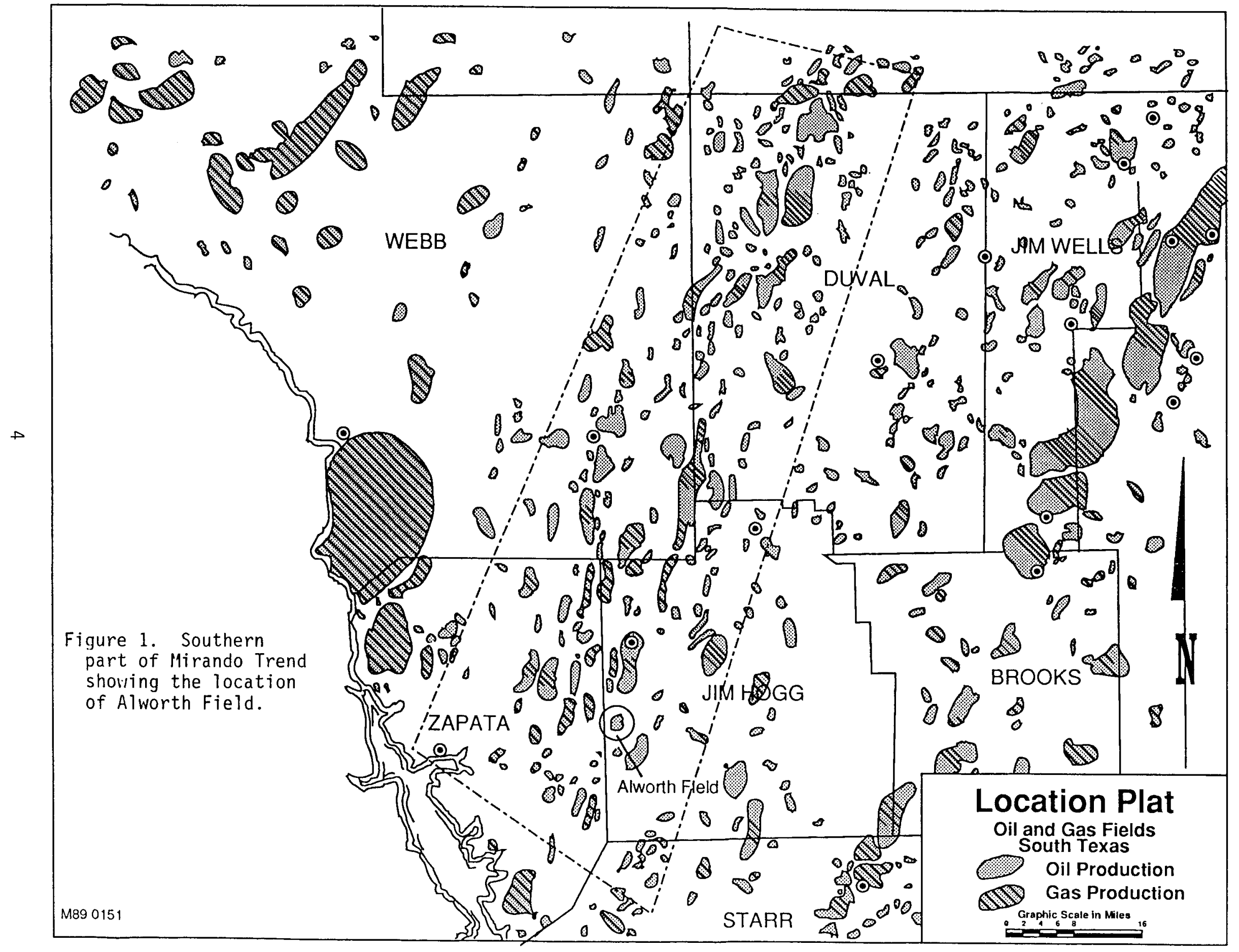


The depths of the producing sands of these fields are between 340 and 3,100 feet below the surface of the ground. The oil recoveries from most, if not all, of these fields could be enhanced by a high temperature/high pressure (HT/HP) brine flood.

\section{High Temperature/High Pressure Deep Brine in the Four County Area of the "Mirando" Trend}

Starting approximately ten years ago, with the discovery and development of the deep Eocene Wilcox gas fields in Duval, Webb and Zapata Counties, it became apparent that a very large deltaic regime existed in these strata in lower South Texas. These sands are correlatable along trend and occur from about 10,000 to 18,000 feet in depth. These overpressured sands have pressure gradients of up to 1 $\mathrm{psi} / \mathrm{ft}$., and bottomhole temperatures of 250 to $500^{\circ} \mathrm{F}$. The trend will continue to receive large exploratory efforts in the future, making cased and logged dry holes available for conversion to HT/HP brine producers.

\section{Alternative Sources of Thermal Oil Recovery}

It is not possible to consider a hot water-steam type flood in this area of South Texas because of the lack of steam quality fresh water. This area is semi-desert and what ground water is present is tightly guarded by the surface owners/ranchers and local and state authorities.

In the San Joaquin Basin, California, cyclic steam injection has been used successfully but is now under scrutiny because of the pollution generated by the equipment used in producing the steam. In contrast, the process suggested here is an environmentally clean process.

\section{Conclusion}

A successful demonstration of an HT/HP brine project, such as the proposed Alworth Field project, would greatly stimulate similar programs along the "Mirando" Trend. The knowledge that flowing hot brine is available almost everywhere under this shallow producing trend would encourage many operators to plan and implement such enhanced oil recovery projects.

Considering the 87 fields in the "Mirando Trend" that produce oil of less than $21^{\circ}$ API gravity, if $20 \%$ initial recovery is assumed to be represented by the 319 million barrels of recovered oil, then over 1.5 billion barrels of oil remain in place that could be the target of thermal enhanced oil recovery. Future exploration, as discussed, would add additional target barrels.

The first HT/HP brine project is logically situated in South Texas from an economic standpoint and operational simplicity. The shallow location of the Alworth Field oil reservoir, simple structure, cost sharing, and relatively low investment by DOE makes the Alworth Field an ideal first target for TEOR using the geopressured resource. 


\section{Index Map of Geopressure Locations}

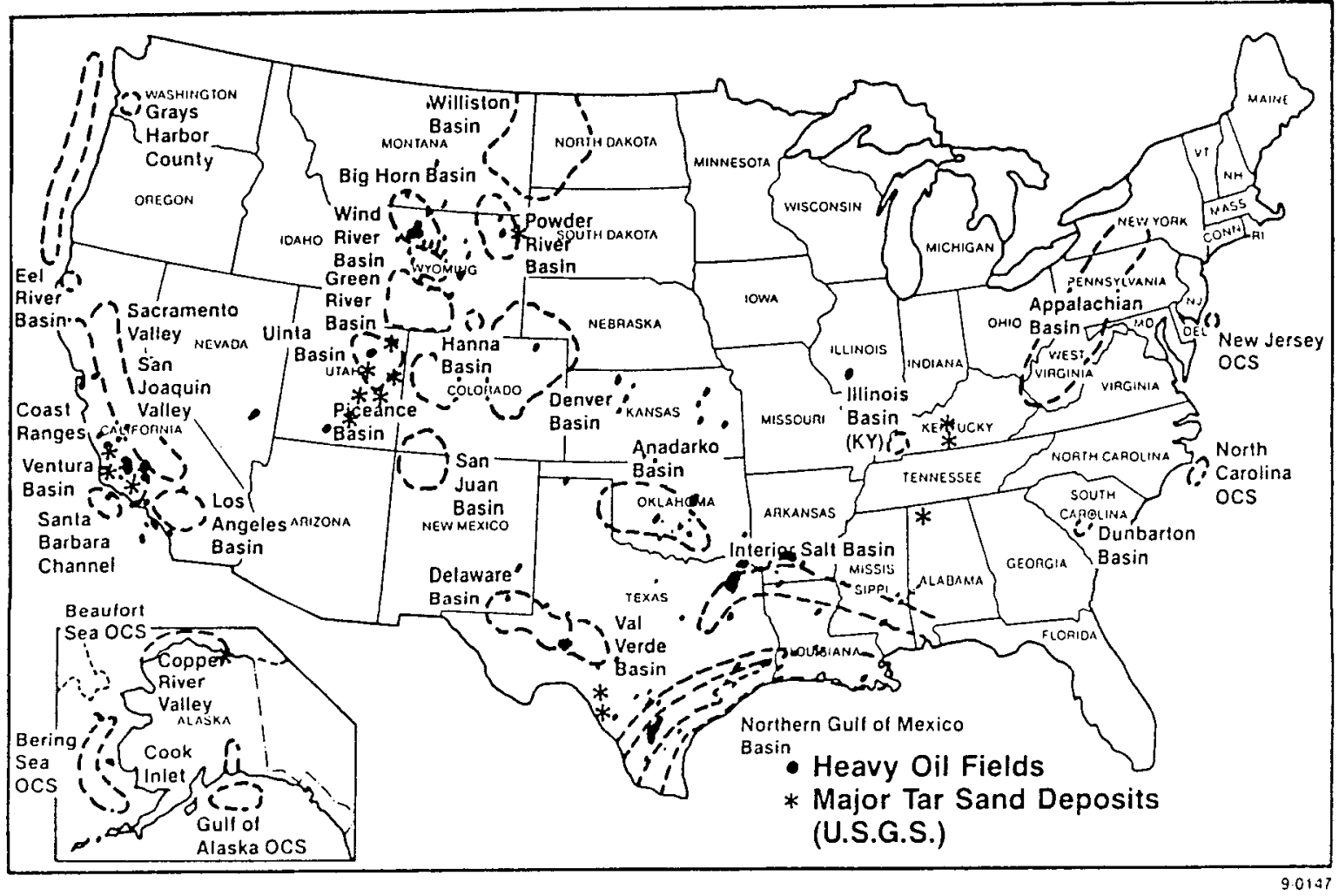

Figure 2. General co-location of geopressure, heavy oil and tar sands. Geopressured regions are shown with dashed lines.

Technical feasibility and economics of application of geopressured-geothermal enhanced recovery of oil is being addressed in a study in progress under the Geopressured-Geothermal Program for FY- 90. Geopressured basins are located in many parts of the United States. Locations are shown with the occurrence of recoverable heavy oil and tar sands in Figure 2 (Negus-de Wys, 1989; Strongin, 1981; and Meyer (U.S.G.S.) 1989, private communication).

The San Joaquin Basin, California, provides most heavy oil production in the United States (see Table 1) and almost all TEOR output in the United States (400,000 BPD). See Table 1. Thermal recovery accounts for about three-fourths of all U. S. EOR production. In Kern County alone, San Joaquin Basin, there are 2.5 billion barrels of recoverable heavy oil reserves at depths of 1,000 to 3,000 feet, with API gravities of $12^{\circ}$ to $23^{\circ}$. The major operators are Texaco, Chevron, Mobil, Shell, Arco, and Unocal; predominantly using cyclic steam for recovery of heavy oil (Williams, 1988; Berry, 1989, private communication). 
Table 1. Leading U. S. basins for ultimate recovery of light, medium, and heavy oil (million bbl)

\begin{tabular}{|l|ccc|}
\hline \multicolumn{1}{|c|}{$\begin{array}{c}\text { Geologic } \\
\text { Province }\end{array}$} & $\begin{array}{c}\text { Light } \\
\mathbf{2 5} \mathrm{API}\end{array}$ & $\begin{array}{c}\text { Medium } \\
20^{\circ}-25^{\circ} \mathrm{API}\end{array}$ & $\begin{array}{c}\text { Heavy } \\
10^{\circ}-20^{\circ} \mathrm{API}\end{array}$ \\
\hline \hline Permian & 24,797 & & \\
Gulf Coast & 23,780 & 1,096 & \\
East Texas & 8,383 & & \\
Louisiana off. & 6,242 & & \\
N. Slope & 6,105 & & \\
San Joaquin & 4,533 & 2,108 & 3,815 \\
Los Angeles & 4,069 & 4,930 & 424 \\
& & & \\
\hline
\end{tabular}

(DOE) 
The western part of the San Joaquin Valley has high geopressures, very low salinity waters, geothermal gradients two times normal, and methane content of 30 to 40 standard cubic feet/barrel (scf/bbl) (Williams, 1981; Berry, 1973; Berry, 1989, private communication).

The Cretaceous section in the San Joaquin Basin is regionally, highly over-pressured and is reputed to have high fluid content; the Tertiary section has high pressures with high fluid content and 15,000 TDS fluid (Berry, 1989, private communication). In the San Ardo area, there are 1-2 billion bbl in place. With consideration of only two (Mirando Trend and Kern County) of the geopressured basins shown in Figure 2, it is possible that thermal enhanced oil recovery with hot geopressured brine could account for 5\% of the 80-100 billion barrels needed for the next 30-40 years in the U.S. (DOE Office of Fossil Energy, August 1989).

If the use of geopressured brine in moving heavy oil can provide even a 5-10\% edge economically, it will be a viable industrial use. Environmentally, the use of geopressured brine would be a cleaner process than the present methods, as well as overcoming the very expensive operational and mechanical problems that occur in heating water on the surface for injection.

If this process is successfully proven domestically, as anticipated, many millions of barrels could be added to this country's recoverable reserves. This would also have application in other countries.

\section{B. GENERAL STATEMENT OF WORK}

The goal of this proposal is to execute a five-year DOE research project, utilizing hot (geothermal), high pressured (geopressured) energy (solution gas and brine) for Thermal Enhanced Oil Recovery (TEOR) of heavy oil from a reservoir in the South Texas Gulf Coast.

This project will be conducted by a joint venture of:

1. EG\&G Idaho, Inc., a scientific and engineering support group, that is presently assisting DOE in managing their Gulf Coast Geopressured-Geothermal Program. They will provide overall direction of scientific effort in such areas as geological and reservoir analysis, environmental monitoring, and economic evaluation of the project through use of their staff, consultants and universities, such as The University of Texas at Austin (UTA).

2. An independent oil company (small business), which will supply the oil reservoir, producing wells, and production system to conduct these tests on a cost sharing basis. They will provide data, assistance and operation of the production wells. They will provide technical support and supervision for drilling and completion of the source well and design, installation and operation of the water flood system, and provide for collection of production and injection data.

This TEOR project will be conducted in the heavy oil (18 API gravity) Cole Sand reservoir in the Alworth Field in Jim Hogg and Zapata Counties, South Texas. It produces about $20 \mathrm{bbl}$ of oil per day, from five producing wells, and is marginally economical. As shown on Figure 3, the viscosity of 18 API gravity oil can be reduced from about 100 centipoise at a temperature of $90 \mathrm{~F}$ to 10 centipoise if the oil is heated to $200 \mathrm{~F}$. Also, there will be thermal expansion of the oil. These effects will increase the mobility of the oil and increase recovery. Based on laboratory studies, reservoir models 


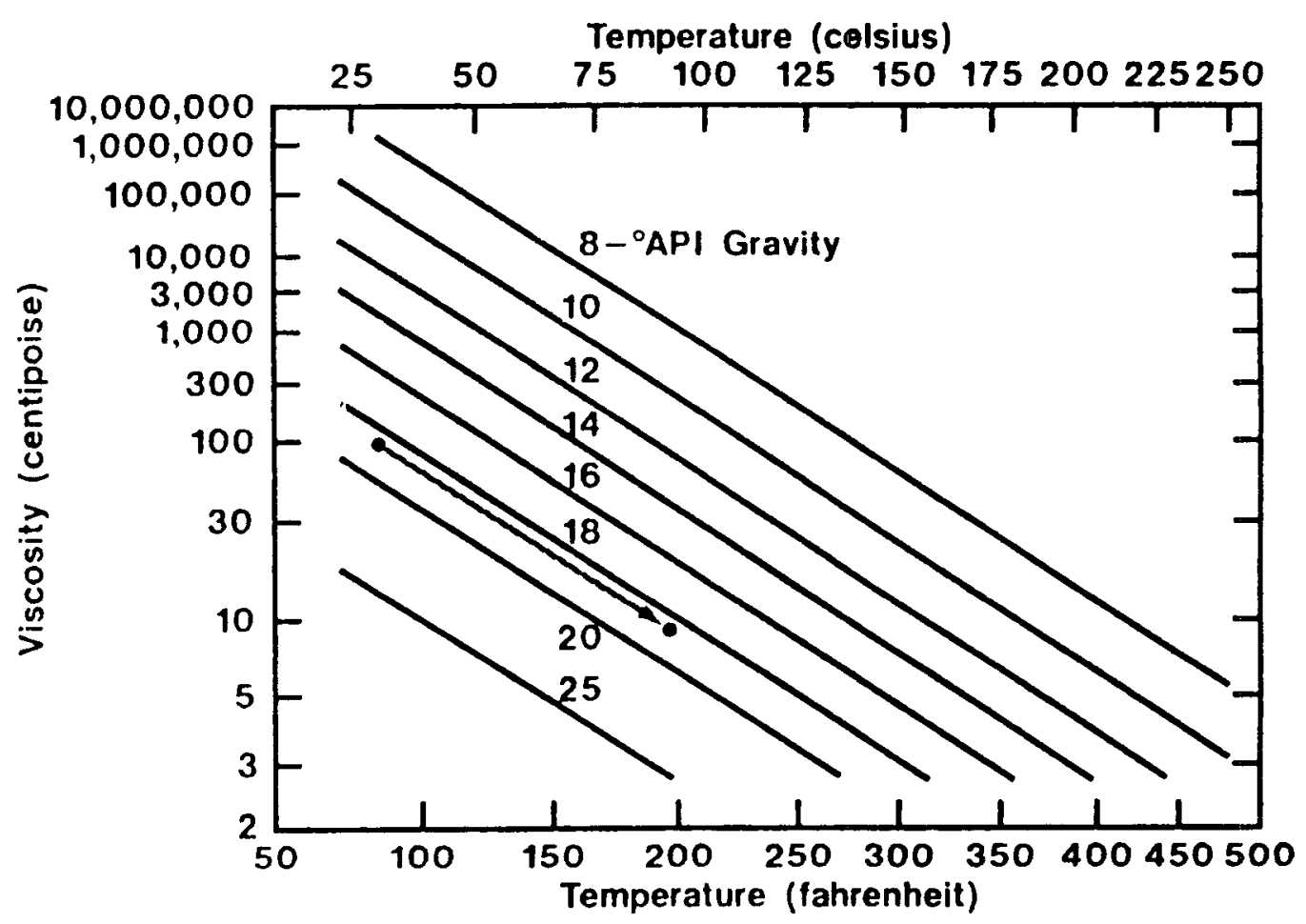

Figure 3. Oil viscosity as function of temperature and gravity. 
and field case histories (Boberg, 1988) incremental oil recovery could be in the range of 10 to $30 \%$ of the original oil in place. The field is presently producing about $1,000 \mathrm{bbls}$ of water per day for a water-cut of about $98 \%$. This water is currently being reinjected in an up-dip position. It is unknown at this point whether this high water-cut is due to water coming from below the water/oil contact or due to channeling from the injection well. Production data are currently available on a field-wide basis only. Therefore, individual wells will be tested to obtain data to assist in determination of the cause of the high water-cut. Methods to resolve the problem will be evaluated and applied as appropriate. Possible methods could include the use of gelled polymer treatments of producing wells, as well as strategically locating the injectors and producers.

A significant increase in recovery can result from a secondary hot waterflood over that of a cold waterflood. By flooding the heavy oil reservoir with hot water, and by stopping injection into the reservoir of cold water produced with the oil, the recovery should increase.

The reservoir (Cole sand) is located at about 1,000 feet depth. The sand has an overall thickness of zero feet at the northern side of the structure, where it shales out, to about 30 feet in the thickest section. The sand has a net oil sand thickness of 15 feet at the crest of the structure, to zero feet at the oil-water contact down dip and where the sand is shaled out up dip. The average net oil sand thickness is 7.5 feet, in an area of about 320 acres. The average porosity of the sand is about $30 \%$, and the average permeability is 1.5 darcies. The total oil-in-place is estimated to be more than three million barrels, of which a minimum of one million barrels is estimated to be mobile oil, recoverable by application of the geopressured TEOR technology.

The geothermal brine will be drawn from a geopressured-geothermal well in the Wilcox formation $( \pm 13-16,000$ feet). Three existing wells, penetrating these reservoirs, are within about $2-1 / 2$ miles of the field. One of these can be re-entered, recompleted, and piped underground to the field for about half the cost of drilling a new well. This well could produce $15-20,000 \mathrm{bbl} /$ day of $400 \mathrm{~F}$, or higher, brine. A preliminary review shows that it is possible to attain the desired temperatures in this system within two years.

This project will be done in phases to minimize government cost and provide go/no-go decision points within the project.

\section{References}

Berry, F. A., 1973, High Fluid Potentials in California Coast Ranges and Their Tectonic Significance: AAPG Bull. Vol 57, pp. 1219-1249.

Boberg, T. C., 1988, Thermal Methods of Oil Recovery: John Wiley and Sons, Inc.

DOE Office of Fissil Energy, August, 1989, Federal Oil Research: A Strategy for Maximizing the Producibility of Known U. S. Oil: DOE/FE-0139.

Kimmell, C. E., 1989, Regional Application of High Temperature - High Pressure Deep Saline Waters for Enhanced Recovery of Oil From Oil Fields Along the Mirando Trend of South Texas: Proposal to DOE.

Negus-de Wys, J., 1989, Properties of Geopressured Brines and Wells in the Gulf Coast and Opportunities for Industrial/Research Participation, Geothermal Resources Council Transactions, Vol 13, pp. 115-122.

Strongin, O., 1981, Identification of Geopressured Occurrences Outside of the Gulf Coast, Phase II, 
Final Report: Science Applications, Inc., McLean, Virginia, 22102, Prepared for DOE Nevada Operations Office, Las Vegas, Nevada, 89114, Under Contract No. DE-AC08-80NV10133.

Williams, B., 1988, California Thermal EOR Expansions Still on Track Despite Low Oil Prices: Oil and Gas Journal 19, December 12, pp. 19-21. 